\title{
Accident rate and degree of consistency on roads in a mountainous area of Perú
}

\section{Siniestralidad y grado de consistencia en las carreteras de una zona montañosa de Perú}

DOI: $10.46932 / \mathrm{sfjdv2n5-035}$

Received in: Oct 1st, 2021

Accepted in: Dec 30th, 2021

\section{Orlando Barreto Jara}

Maestro en Economía. Mención Gestión Pública y Desarrollo Regional

Departamento Académico de Ingeniería Civil. Universidad Nacional de San Antonio Abad del Cusco.

Av. de La Cultura 773, Cusco, Perú

E-mail: orlando.barreto@unsaac.edu.pe

\section{Urpi Barreto Rivera}

Máster en Planificación y Gestión en la Ingeniería Civil

Departamento Académico de Ingeniería Civil. Universidad Nacional de San Antonio Abad del Cusco.

Av. de La Cultura 773, Cusco, Perú

E-mail: urpi.barreto@unsaac.edu.pe

\section{Yasser Abarca Sánchez}

Magister en administración estratégica de negocios

Departamento Académico de Administración. Universidad Continental

Urb. Ucchullo Grande P-6, Cusco, Perú

E-mail: yabarca@continental.edu.pe

\section{Gabriel Suyo Cruz}

Doctor en Dirección de Empresas

Departamento Académico de Ciencias Administrativas. Universidad Nacional de San Antonio Abad del Cusco

Av. de La Cultura 773, Cusco, Perú

E-mail: gabriel.suyo@unsaac.edu.pe

\section{Jorge Luis Diaz Ugarte}

Maestro en Administración. Mención Gestión Pública y Desarrollo Regional

Departamento Académico de Ciencias Administrativas. Universidad Nacional de San Antonio Abad del Cusco

Av. de La Cultura 773, Cusco, Perú

E-mail: jorge.diazu@unsaac.edu.pe

\section{RESUMEN}

En el Perú, según los reportes históricos, la infraestructura vial no constituye un motivo de accidentes de tránsito; a pesar de que, según el estado del arte, los accidentes de tránsito se encuentran entre los diez primeros motivos de accidentes mortales a nivel mundial, hecho que es aún más visible en los países subdesarrollados. Los estudios sobre relieves montañosos (realidad de los países andinos) y para vehículos de carga son escasos. Por esta razón, se tomó como unidad de análisis una vía principal correspondiente a la red vial nacional, el objetivo fue establecer el nivel de consistencia de las vías de estudio y su incidencia en los accidentes de tránsito. Para ello, se establecieron los tramos críticos y su correspondencia 
con los accidentes de tráfico; se incorporaron al análisis tres tipos de vehículos (ligeros, de pasajeros y de carga); se utilizó la metodología de análisis de consistencia, en su modalidad de velocidad de operación para establecer los tramos críticos; se analizó la carretera bajo el criterio local y el criterio continuo. Los resultados muestran que existen tramos inconsistentes; el criterio local explica mejor la inconsistencia de la unidad de análisis respecto al criterio continuo. Con la regresión de Poisson, el modelo integral es significativo; las variables independientes optimizan conjuntamente el modelo.

Palabras-clave: consistencia de la carretera, velocidad, velocidad de diseño, accidentalidad, accidentabilidad.

\begin{abstract}
In Peru, according to historical reports, road infrastructure does not constitute a reason for traffic accidents; despite the fact that, according to the state of the art, traffic accidents are among the top ten reasons for fatal accidents worldwide, a fact that is even more visible in underdeveloped countries. Studies on mountainous reliefs (reality of the Andean countries) and for cargo vehicles are scarce. For this reason, a main road corresponding to the national road network was taken as the unit of analysis, the objective was to establish the level of consistency of the study roads and their incidence in traffic accidents. To this end, the critical sections and their correspondence with traffic accidents were established; three types of vehicles (light, passenger and cargo) were incorporated into the analysis; the consistency analysis methodology was used, in its operating speed modality to establish the critical sections; the road was analyzed under the local criterion and the continuous criterion. The results show that there are inconsistent sections; the local criterion explains better the inconsistency of the unit of analysis with respect to the continuous criterion. With Poisson regression, the integral model is significant; the independent variables jointly optimize the model.
\end{abstract}

Keywords: road consistency, speed, design speed, accident rate, accidentability

\title{
1 INTRODUCTION
}

The State, within its road safety policy guidelines, establishes global objectives for the year 2024 to address the accident rate in accordance with the United Nations; however, government actions have a reactive character, where the causes of accidents point basically to human attitudes or behaviors (speeding, recklessness, drunkenness and disregard of signals by the driver, recklessness of pedestrians, etc.), and not to the road infrastructure and environment, etc. In other words, the road and its environment are also part of the cause of traffic accidents, however, it is a less known and less studied aspect. Roads are designed according to technical standards that change and improve over time, with increasingly strict criteria for road safety. Many of these roads were built many years ago and their geometric design presents critical sections that should be evaluated to observe their relationship with traffic accidents, and thus establish a model through the behavior of road users to be able to contribute to the policies established to reduce the accident rate.

The geometric design of roads in Peru, according to the Manual of Geometric Design of Roads, have been carried out according to a specific Guideline Speed, this situation is based on simplified models 
of reality, where a hypothetical model of driver behavior is inferred that develops a constant speed. In reality, the attitude of drivers is to travel at a different speed than the Guideline Speed (usually higher), at whose speed we call "Operating Speed ". A driver prints a certain speed on the road according to his expectation that he has on the road. Therefore, when there are differences in Operating Speed with respect to the Guideline Speed in the different sections of the road, inconsistencies are generated which are those sectors of danger and occurrence of accidents[1], a situation that was being verified in a series of investigations carried out later.

The general objective of this study was to determine the degree of consistency of the study road and to analyze its impact on the accident rate. In addition, we sought to establish the independent relationships between accident rate and consistency, with the Average Daily Index (ADI), with the length of each analyzed section of the road, in order to finally perform a multivariate relationship. Different techniques and instruments of direct measurement in the field were used, the research is framed within the quantitative type, with a nonexperimental, correlational explanatory-predictive design, with an independent variable that is the consistency of the geometric design versus the accident rate in the road under study.

\section{THEORETICAL BASIS}

In a road project, the most important part is the geometric design, satisfying demands such as safety, functionality, economy, comfort, aesthetics and environmental integration. The safety aspect has traditionally been associated with compliance with traffic regulations, but new road design processes revolve fundamentally around road safety [2]. The evaluation of road safety from the geometric design is carried out by locating sections of danger of the occurrence of traffic accidents. Traffic accidents cannot be attributed to a single cause, they are the final result of a complex sequence of actions and interactions between the components of the so-called Road Safety System: human factor, the road with its environment and the vehicle. There are models to evaluate and predict accidents such as the Interactive Highway Safety Design Model (IHSDM) of the Federal High Way Administration (FHWA) of the USA; however, the reality of the case study is different, so the work was carried out with the inconsistencies model of the subject matter pathway.

On the other hand, within the strategies for evaluating the issue of road safety, there is the concept of the accident concentration segment, which corresponds to sections that present an average long-term risk significantly higher than the average in sections with similar characteristics [3], which means that it is essential to identify these sections and have a timely action to improve the road infrastructure, which can lead to an effective reduction of the accident rate. There are models to determine road safety, such as 
"linear", "multiplicative" (such as the IHSDM) and "modifiers", which will depend on the orientation of the study, depending on the resources available to the researcher [4].

\subsection{VIAL CONSISTENCY}

The consistency in road geometric design refers to the fact that the variations in operating speed of the vehicles that develop along the road are not very divergent and that said speed does not differ significantly from the design speed. The consistency evaluation is carried out to know the situation of the safety of the traffic of the road users. In other words, the safety of existing roads is mainly determined by the number of traffic accidents that occur due to different geometric factors [5]. It has also been demonstrated that road safety (understood in terms of accident rate) increases as consistency decreases [6], [7].

Table 1. Relationship between consistency and loss ratio [7]

\begin{tabular}{ccc}
\hline $\begin{array}{c}\text { Consistency } \\
\text { according to Lamm }\end{array}$ & $\begin{array}{c}\text { Number of } \\
\text { curves }\end{array}$ & $\begin{array}{c}\text { Loss rate (Accid / 106 } \\
\text { veh-km) }\end{array}$ \\
\hline Good & 4518 & 0.46 \\
\hline Acceptable & 622 & 1.44 \\
\hline Bad & 147 & 2.76 \\
\hline
\end{tabular}

It should be noted that the design speed is theoretical (and in reality it is below the average operating speeds), since during the execution of the project the geometric elements may vary (superelevation, radius, angle of deflection, in that order ) or be affected by other situations in the environment; generally the design speed is surpassed by the majority of the drivers [8], so it is important to work with primary data; as are the operating speeds. Understanding how the particularities of the driver (mainly the expectation and their level of attention) determine the driving task of the vehicular movement (information processing and decision making), is essential to understand how the geometry of the road is key in road safety. That is, there is a driver's workload (mental effort), which becomes more demanding the more complex the geometry is, where inconsistencies demand more attention, so drivers who take too long to process the information, can commit speed and / or trajectory errors that increase the possibility of accidents [8].

Road consistency analysis has several approaches [9], although from a practical point of view, they are reduced to local and global consistency analysis [2]. At the local level, Lamm proposes three criteria of threshold values to qualify consistency [10], of which the first two criteria (I and II) were applied in the present work. 
Table 2: Lamm consistency criteria [10]

\begin{tabular}{|c|c|c|c|c|}
\hline Criterion & $\begin{array}{c}\text { Geometric } \\
\text { Element }\end{array}$ & Curvature Change Rate Interval & $\begin{array}{l}\text { Consistency } \\
\text { Criterion }\end{array}$ & $\begin{array}{c}\text { Design } \\
\text { Qualification }\end{array}$ \\
\hline \multirow[t]{3}{*}{$\mathrm{I}$} & \multirow{3}{*}{$\begin{array}{l}\text { Simple } \\
\text { Curves }\end{array}$} & CCRi $\leq 180 \mathrm{~g}$ & $\mathrm{ICI} \leq 10(\mathrm{~km} / \mathrm{h})$ & Good \\
\hline & & $180 \leq \mathrm{CCRi} \leq 360 \mathrm{~g}$ & $10 \leq \mathrm{ICI} \leq 20$ & Fair \\
\hline & & $\mathrm{CCRi}>360 \mathrm{~g}$ & $\mathrm{ICI}>20(\mathrm{~km} / \mathrm{h})$ & Poor \\
\hline \multirow[t]{3}{*}{ II } & \multirow{3}{*}{$\begin{array}{l}\text { Successive } \\
\text { Curves }\end{array}$} & $|\mathrm{CCRi}-\mathrm{CCRi}+1| \leq 180 \mathrm{~g}$ & ICII $\leq 10(\mathrm{~km} / \mathrm{h})$ & Good \\
\hline & & $180 \leq|\mathrm{CCRi}-\mathrm{CCRi}+1| \leq 360 \mathrm{~g}$ & $\begin{array}{c}10 \leq \mathrm{ICII} \leq 20 \\
(\mathrm{~km} / \mathrm{h})\end{array}$ & Fair \\
\hline & & $|\mathrm{CCRi}-\mathrm{CCRi}+1|>360 \mathrm{~g}$ & ICII > $20(\mathrm{~km} / \mathrm{h})$ & Poor \\
\hline
\end{tabular}

At the global level, the assumed model is the one proposed by Polus and Mattar [11] and is based on continuous speed profiles, determined by the variations in operating speeds with respect to the average in that segment, resulting in a single value of consistency for the selected stretch of road, through two consistency measures. In the assumed model, the authors developed two new consistency measures based on the operation profiles. The first is determined based on the area enclosed between the speed profile and the average speed of the section (in this case, a1, a2 and a3), as shown in Figure 1.

Figure 1: Example of a speed profile on a section of track

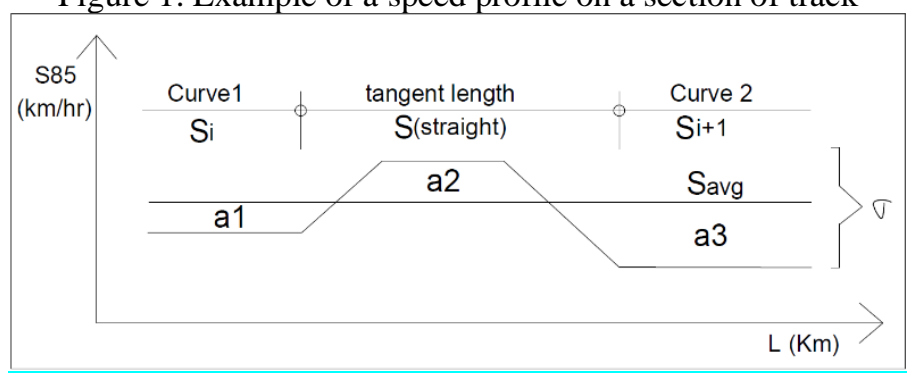

Note: Si: Operating speed in the previous curve or curve $1 ; \mathrm{Si}+1$ : Operating speed on the back curve or curve $2 ; \mathrm{S}$ (straight): Maximum desired speed on the straight; Savg: Average speed.

$$
R_{a}=\frac{\sum_{i=1}^{n}\left|a_{i}\right|}{L}
$$

$\mathrm{Ra}=$ Measure of consistency of relative area $(\mathrm{m} / \mathrm{s})$

ai $=$ Area between the velocity at each point of the profile and average speed $(\mathrm{m} 2 / \mathrm{s})$

$\mathrm{L}=$ Length of the section $(\mathrm{km})$

The second measure is $\sigma$, which is the standard deviation of the operating speed in each element of the design along the study section:

$$
\sigma=\sqrt{\frac{\sum_{i=1}^{n}\left(V_{i}-V_{a v g}\right)^{2}}{n}}
$$

$\sigma=$ Standard deviation of operating speeds $(\mathrm{km} / \mathrm{h})$

$\mathrm{n}=$ Number of elements in the section

$\mathrm{Vi}=$ Operating speed in each element or alignment $(\mathrm{km} / \mathrm{h})$ 
Likewise, the authors in question established limits for Ra and $\sigma$ (Table 3), based on which the consistency could be considered good, acceptable or poor. From these two measures, they developed a consistency index based on a negative exponential type function:

$$
C_{2}=2,808 \dot{e}^{-0.278\left[R_{a}\left(\frac{\sigma}{3.6}\right)\right]}
$$

Table 3. Thresholds for determining the quality of design consistency [11]

\begin{tabular}{|c|c|c|}
\hline \multicolumn{3}{|c|}{ Consistency level } \\
\hline Good & Fair & Poor \\
\hline$R_{\mathrm{a}} \leq 1 \mathrm{~m} / \mathrm{s}$ & $1<\mathrm{Ra} \leq 2 \mathrm{~m} / \mathrm{s}$ & $\mathrm{Ra}>2 \mathrm{~m} / \mathrm{s}$ \\
\hline$\sigma \leq 5 \mathrm{~km} / \mathrm{h}$ & $5<\sigma \leq 10 \mathrm{~km} / \mathrm{h}$ & $\sigma>10 \mathrm{~km} / \mathrm{h}$ \\
\hline $\mathrm{C}_{2}>2 \mathrm{~m} / \mathrm{s}$ & $1<\mathrm{C}_{2} \leq 2 \mathrm{~m} / \mathrm{s}$ & $\mathrm{C}_{2} \leq 1 \mathrm{~m} / \mathrm{s}$ \\
\hline
\end{tabular}

In the present study, both approaches have been developed to take a more panoramic view of the case of claims on the test road, placing greater emphasis on the continuous or global evaluation model, which offers a consistency value for an entire segment or study section (several curves and tangents), through a consistency index, so that a greater dispersion of operating speeds in that segment, would mean a road with high geometric changes in its layout or less consistency, therefore greater accident risk [12].

\subsection{OPERATING SPEEDS}

The great problem for road organizations is to see the control of accidents from a pragmatic point of view (stricter application of laws and regulations and firmer penalties, frequent control of technical reviews of vehicles, more frequent police presence, the need for better driver education and stricter tests, etc.), versus a more rational style, as Hauer points out, that it is the result of efficiently reducing the damage from crashes [13]; that is, using objective information through factual knowledge such as research. The operating speed is the one that corresponds to the maximum speed at which vehicles can circulate in a certain section of a highway based on the design speed under prevailing traffic conditions [14]. This speed is not the same for all vehicles, so at the international level it is considered the one corresponding to the 85 th percentile; that is, the one that would foreseeably only be surpassed by $15 \%$ of drivers and therefore covers the majority of drivers [15].

Regarding the factors that influence operating speeds, on rural two-lane highways, they depend on the behavior of the drivers, the road environment, radii of horizontal curves, rate of change of curvature, angle of deflection, length of horizontal curves, deviation angle, visibility distance, superelevation, lateral friction factor, slopes, pavement conditions, etc., with the radii, length of a certain element and longitudinal slopes being the ones with the greatest incidence [16] . Vehicle speed is currently considered as a basic aspect of public policy, engineering and road safety, being a road safety problem par excellence. 
The great probability of accidents is the variation of speeds with respect to the average speed of traffic, whose relationship between the speed of the vehicle and the accidents presents a curve in the shape of a "U" [17]. This fact is important, because the speed variation will depend on the geometry of the road, represented by horizontal curves, cants, angle of deflection, etc.

\section{MATERIALS AND METHODS}

\subsection{TEST ROAD AND SECTIONS}

The test road was selected directly, according to the following criteria: (i) continuous curvilinear alignment (ii), altitudinal location greater than 3,000 meters above sea level, (iii) mixed traffic, (iv) paved road of two lanes and (v) undulating-rugged relief, as represented by the Cusco-Urcos highway, which corresponds to the $\mathrm{P} 3 \mathrm{~S}$ national route, with a distance of $31.85 \mathrm{~km}$, a running surface width of $6.20 \mathrm{~m}$ and berms of $0.60 \mathrm{~m}$. The unit of analysis corresponds to the entire road alignment, which comprises a continuous curvilinear one as it is linked by tangents and circular curves in different directions, as can be seen in Fig. 2.

Figure 2. Continuous curvilinear alignment, where points A (at 2/3 of the tangent) and B (center of horizontal curve), where gait speed measurements were made, for a bi-directional road.

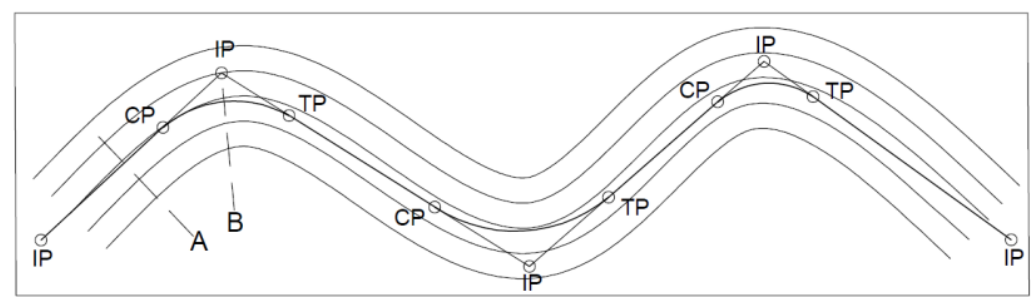

The sections were defined following criteria of homogeneity in terms of constant traffic intensity or with small variations along the section and physical characteristics of the road (width and number of lanes, speed limit, number of intersections and characteristics of the median), being 800.00 meters (except for one section), the minimum length of a section to have reliable results.

Table 4: Study sections

\begin{tabular}{cccc}
\hline Section & \multicolumn{2}{c}{ Progressive } & Length of \\
& Initial & Last & section \\
\hline section 1 & $984+200$ & $987+083$ & 2882.88 \\
section 2 & $987+447$ & $991+996$ & 4549.58 \\
section 3 & $992+730$ & $993+137$ & 406.34 \\
section 4 & $995+359$ & $997+892$ & 2533.54 \\
section 5 & $998+640$ & $999+661$ & 1021.64 \\
section 6 & $999+761$ & $1002+563$ & 2802.01 \\
section 7 & $1002+660$ & $1006+188$ & 3528.03 \\
section 8 & $1006+552$ & $1008+955$ & 2402.58 \\
section 9 & $1009+588$ & $1013+295$ & 3706.64 \\
section 10 & $1014+043$ & $1015+079$ & 1036.06 \\
\hline
\end{tabular}


To know the physical aspect of the road, an aerial photographic survey was carried out using an unmanned aerial vehicle (UAV), DJI Phantom 4 drone, at a height of $30 \mathrm{~m}$, prior to a ground control, using control bands of two points each. 1500 meters. For the digital processing of the information, the Generated with Drone2Map for ArcGIS software was used (to process 7,200 photographs), whose final product is the horizontal and vertical alignment of the road, in AutoCad format.

\subsection{VEHICULAR TRAFFIC}

The traffic study was carried out for 24 continuous hours in a period of 7 days. The gauging points were located in four sectors according to the homogeneity of the traffic and topography, which can be seen in Table 5. At station 3, the traffic is above 7,590 vehicles / day, which means that the study road is within the 1st class highway classification. Light traffic corresponds to $69 \%$ and heavy to $31 \%$.

Table 5. Current Average Daily Index (ADI) of the Cusco-Urcos road

\begin{tabular}{c|c|c|c|c|c}
\hline \multirow{2}{*}{ Station } & $\begin{array}{c}\text { Cars and } \\
\text { trucks }\end{array}$ & Buses & Trucks & $\begin{array}{c}\text { Articulated } \\
\text { trucks }\end{array}$ & $\begin{array}{c}\text { Average } \\
\text { diary } \\
\text { (veh / day) }\end{array}$ \\
\hline 1 & 38105 & 16448 & 5740 & 2097 & 8913 \\
\hline 2 & 43175 & 8765 & 3347 & 987 & 8039 \\
\hline 3 & 39616 & 7881 & 4269 & 1364 & 7590 \\
\hline 4 & 17685 & 6242 & 4429 & 1814 & 4310 \\
\hline Average & 4949 & 1405 & 635 & 224 & $\mathbf{7 2 1 3}$ \\
\hline Percentage & $69 \%$ & $19 \%$ & $9 \%$ & $3 \%$ & 100 \\
\cline { 2 - 6 }
\end{tabular}

\subsection{ACCELERATION AND DECELERATION RATES}

Operating speed on a road varies based on two factors: the speed on the different road segments (curves and tangents) and the speed adjustments that occur when transitioning between the segments. An example of these adjustments is the deceleration that originates when entering a curve and the acceleration, that when exiting it, which determines that the speed profiles will be different in all sections [18]. The value of $0.85 \mathrm{~m} / \mathrm{sec} 2$ is assumed for acceleration and deceleration, assuming that all the change in deceleration occurs on the straight and all the change in acceleration in curves, recommended values for evaluations of consistency of road designs conventional [8], [19]

\subsection{OPERATING SPEEDS}

Operating speeds are measurements in the field at the speeds of vehicles traveling on the road. In order to cover a broader vehicle composition, where light vehicles, buses with all axles and two-axle trucks are the ones with the highest proportion, the number of readings on each type of vehicle in both 
directions of circulation and for each geometric element (curves and tangents). A specific sample size (N) was required to satisfy statistical requirements [20]:

$$
N=\left(\frac{S K}{E}\right)^{2}
$$

$\mathrm{N}=$ Minimum sample size

$\mathrm{S}=$ Estimated standard deviation of the sample ( $\mathrm{km} /$ hour $)$

$\mathrm{K}=$ Constant that corresponds to the desired confidence level

$\mathrm{E}=$ Allowable error in speed estimate

There was no speed analysis prior to the present study to be able to determine the standard deviation of operating speeds, so recommendations from the literature were used [20], the value of $8 \mathrm{~km}$ / hour was assumed as "S", the constant "K" depends on the level of confidence (the probability that the mean speed is a valid estimate), $\mathrm{K}=2$ is assumed (for a confidence level of $95.5 \%$ ), which includes errors in the measurement instrument, in drivers when driving. feeling observed and the operator of the measuring equipment [20]. The allowed error "E" depends on the precision that the researcher wants to give to his work, where this measure is an absolute tolerance that means that the absolute error is specified as $+/$ - of a selected value, with 30 being the minimum value of the sample size, a value of "E" $=+/-2.0$ $\mathrm{km} /$ hour was taken, which includes errors in the measurement instrument, in the drivers when they feel observed and the equipment operator. Source: Manual of Traffic Engineering Studies. Volume VII. Directorate General for Land Use Planning. SEDESOL. Mexico. Therefore, 64 measurements were taken for each element (curve and tangent), for each type of vehicle to be studied, round trip. In total, for 120 elements, 46,080 readings were taken.

For the speed readings, the PC and PT of each horizontal curve were established, materializing by painting on the road, as well as the midpoint of each curve. Using the Operation Speed Collection Sheet, speed data was collected using the speed radar, model 101911, Bushnell brand (accuracy $+/-1 \mathrm{mph},+/-2$ $\mathrm{kph}$ ), both in the horizontal curves and on the tangents, for each type of vehicle selected (cars, buses and trucks with two axles), in both outward and return directions, according to what is indicated in Figure3. 
Figure 3. Scheme for capturing operating speed readings 3.5 Speed profiles

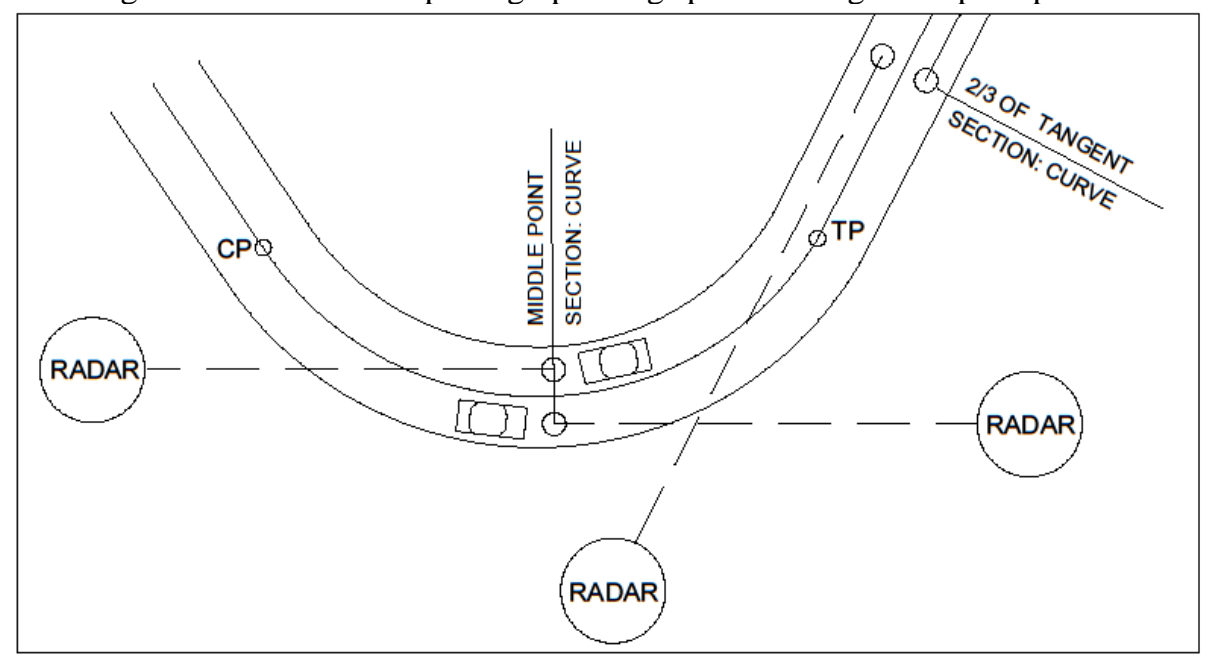

A good way to represent the operating speed on the general alignment is the speed profile, which allows to compare the V85 with the design speed, or as in the present case with the specific speeds, and identify the critical sections where the operating speeds are above those offered by the road. For the construction of the speed profile, the desired speed is required in the straight sections, a value that is not always available, so they usually assume the legal limit speed [21], incurring an error because it should correspond to the 98th percentile operating speed. The models of speed profiles normally choose discrete models of estimation of speeds in curves and in straight lines, to later join them using a criterion regarding the rates of deceleration and acceleration. Then a continuous speed profile is obtained on a section of track to later determine the consistency indices, there being a dependency relationship between the speed within the intermediate tangent (LR) and its length, and the speeds S85 of curves 1 and 2 [1], [8], [19]. For example, case 1 represents a line length between curves large enough so that the desired speed can be reached on the line (SR) and that this speed can be maintained. In case 2, LR, it is smaller so that the desired speed can be reached on the SR line, but it cannot be maintained. In case 3, LR is smaller than that of case 2, which does not allow reaching the desired speed, but a lower speed SR. In case 4, LR is very small that, to go from one curve to the other, it only remains to decelerate (or accelerate if S1 is less than S2). That is, the desired maximum speed that a vehicle can reach on a straight line, may or may not be achieved depending on the length of said tangent. 
Figure 4. Speed profiles as a function of the length of the line between curves [12]

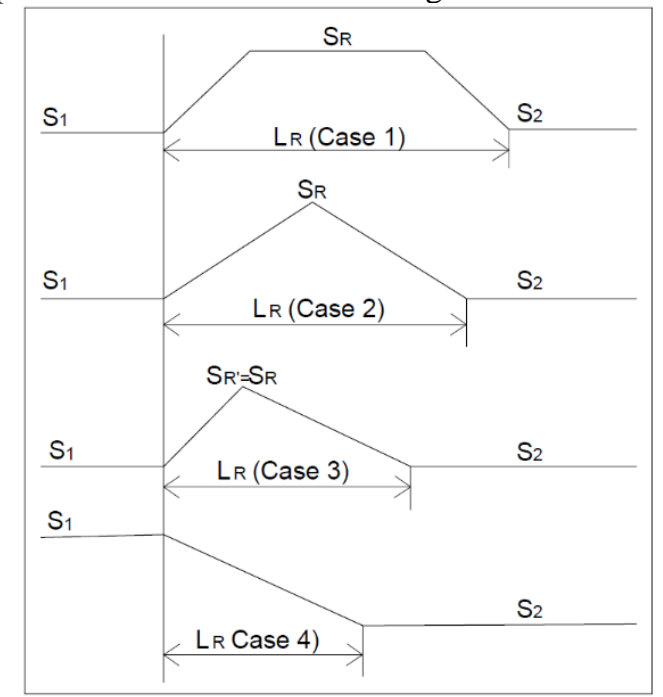

Note:

S1: speed in the previous curve

$\mathrm{S} 2$ : speed on the next curve

SR: maximum desired speed on the straight

SR': speed reached on the straight

LR case $i$ : length of the line between the two curves in case $i$

\subsection{SPEED DISTRIBUTION IN CURVES}

The distribution of speeds in the curves was analyzed with the data recorded in the field, whose assumed hypothesis is that there is a normal distribution of operating speeds in all the elements studied. For each case, the histograms were determined, such as the normal distribution and the accumulated normal distribution, corresponding to the adjustment of the normal distribution for the mean and standard deviation of the data in each case. In all cases, the velocity distribution fits a normal distribution (Figure 5). This allows the most common statistical procedures to be carried out, taking into account that in cases in which the p-value is greater than or equal to 0.05 , the hypothesis that the variable comes from a normal distribution with $95 \%$ cannot be rejected. trustworthy. For the normality test, the Kolgomorov-Smirnov test (Table 9) was used, where it is concluded that the hypothesis that the velocities measured in the field cannot be rejected, behave as a normal distribution, for any level of significance. less than 0.33715 . 
Figure 5. Normal distribution of velocities of the elements studied. As an example: curve 1.

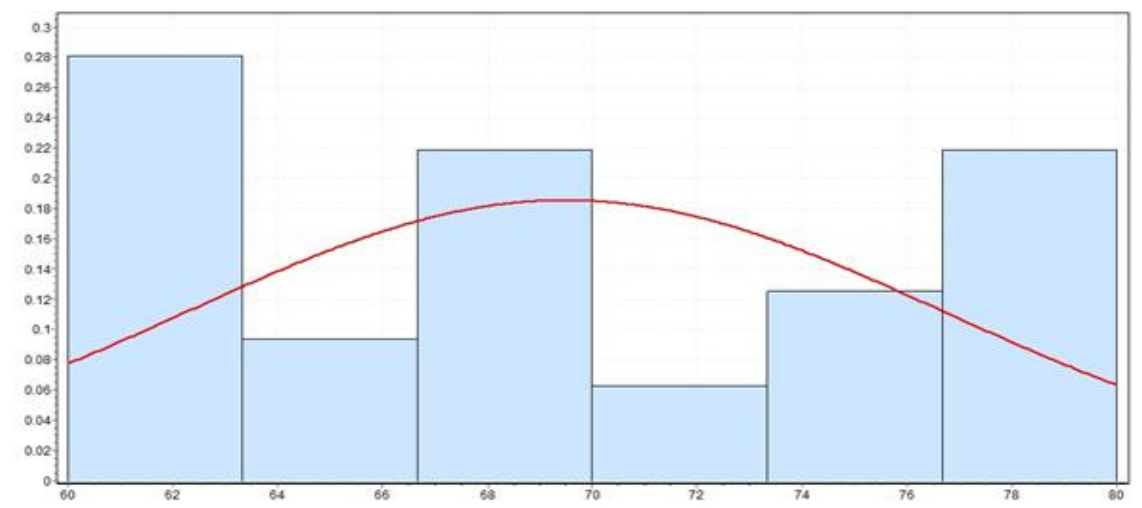

Table 6: Normality test by Kolmogorov-Smirnov

\begin{tabular}{|c|c|c|c|c|c|}
\hline Sample size & & 64 & & & \\
\hline Statistics & & 0.11523 & & & \\
\hline$P$ value & & 0.33715 & & & \\
\hline Rank & & 5 & & & \\
\hline $\mathrm{A}$ & 0.2 & 0.1 & 0.02 & 0.02 & 0.01 \\
\hline Critical value & 0.13511 & 0.15027 & 0.16693 & 0.18667 & 0.20029 \\
\hline To refuse? & No & No & No & No & No \\
\hline
\end{tabular}

\subsection{DETERMINATION OF THE $85^{\mathrm{TH}}$ PERCENTILE}

Using the SPSS statistical program, results were obtained from the frequency distribution of operating speeds in cars, buses and trucks (in both directions of the road).

\subsection{ESTIMATION OF EXPECTED ACCIDENTS BASED ON CONSISTENCY}

The first studies that were carried out to relate the consistency of a section or associated variables and the accident rate were developed from the 70's. In previous investigations, accidents have been estimated from variables related to consistency, but not directly with a consistency index. In 2004, Polus and Mattar-Habib, related the number of accidents with the consistency of the road measured from an integrated consistency index [11]:

$$
\mathrm{Y}=1.051 \times \mathrm{e}^{-0.377 \times \mathrm{C}_{2}}
$$

$\mathrm{Y}=$ Expected number of accidents (Acc / 106 Veh-km)

$\mathrm{C}_{2}=$ Consistency index defined by Polus and Mattar-Habib (2004)

In 2008 Mattar-Habib, related the number of accidents with road consistency [11], using a Poisson distribution, measured from the consistency index defined by Polus and Mattar-Habib. They conducted two analyzes, one with data from Israel, and the other with data from Germany. They estimated the number of accidents based on the consistency, the volume of traffic and the length of the road section. 
The model developed for Israel was:

$$
\log \left(y_{i}, 5\right)=\log \left(1.256 \times 10^{-5}\right)+1.677 \log (A D I)+0.061 L-0,228 C_{2}
$$

The model developed for Germany was:

$$
\log \left(y_{i}, 3\right)=\log \left(6.902 \times 10^{-3}\right)+0.635 \log (A D I)+0.226 L-0,114 C_{2}
$$

Where:

Yi, $5=$ Accidents expected for 5 years

Yi, $3=$ Accidents expected for 3 years

ADI: Average daily traffic intensity (Veh / day)

$\mathrm{L}=$ Section length $(\mathrm{km})$

$\mathrm{C} 2=$ Consistency index defined by Polus and Mattar-Habib.

One of the important data to contrast the expected results is that corresponding to the occurrence of traffic accidents on the road in this case study. After reviewing the sources of information, it is appreciated that there is no complete or orderly record of the events. Knowing the relationship between consistency and accident rate, the number of accidents can be estimated that allows evaluating whether a route is good, acceptable or poor.

\section{RESULTS}

\subsection{VIAL CONSISTENCY}

\subsubsection{Local consistency analysis}

The consistency analysis was performed by simple curves and successive curves according to criteria I and II described by Lamm, as shown in Table 7, which corresponds as an example, for the Piñipampa sector section, they determined the specific speeds in each curve, through the radius formula, whose cant was determined in the field. The colors indicate the degree of consistency. The "good" rating corresponds to a consistent design, which does not require substantive modifications to the alignment. The "fair" rating corresponds to a design that can tolerate a certain degree of inconsistency if it is close to the "good" rating, but may require redesign if it is close to the "bad" threshold and may eventually require maximum speed signs. Lastly, the "bad" rating requires a redesign. 
Table 7. Road consistency for simple and successive curves, for the Piñipampa sector section. Direction Cusco-Urcos.

\begin{tabular}{|c|c|c|c|c|c|c|c|c|c|c|}
\hline \multirow[t]{2}{*}{ Element } & \multirow{2}{*}{$\frac{\text { Ve }}{\mathrm{Km} / \mathrm{hr}}$} & \multicolumn{3}{|c|}{$\begin{array}{c}\mathbf{V} \text { of operation }(\mathbf{V} 85) \\
(\mathrm{Km} / \mathrm{hr})\end{array}$} & \multicolumn{3}{|c|}{ Difference (V85) - (Ve) } & \multicolumn{3}{|c|}{$\begin{array}{l}\text { Difference }(\mathbf{V} 85) \text { - } \\
(\mathbf{V} 85(\mathrm{n}-1))\end{array}$} \\
\hline & & $\mathrm{A}$ & $\mathrm{B}$ & $\mathrm{C} 2$ & $\mathrm{~A}$ & $\mathrm{~B}$ & $\mathrm{C} 2$ & $\mathrm{~A}$ & $\mathrm{~B}$ & $\mathrm{C} 2$ \\
\hline Curve & 73.7 & 74.00 & 78.00 & 59.00 & 0.32 & 4.32 & 14.68 & 9.25 & 1.00 & 15.00 \\
\hline Tangent & & 81.00 & 86.00 & 65.00 & & & & 7.00 & 8.00 & 6.00 \\
\hline Curve & 47.3 & 75.00 & 72.00 & 59.00 & 27.68 & 24.68 & 11.68 & 6.00 & 14.00 & 6.00 \\
\hline Tangent & & 79.00 & 76.00 & 62.00 & & & & 4.00 & 4.00 & 3.00 \\
\hline Curve & 61.5 & 73.00 & 56.00 & 59.25 & 11.49 & 5.51 & 2.26 & 6.00 & 20.00 & 2.75 \\
\hline Tangent & & 80.00 & 62.00 & 65.25 & & & & 7.00 & 6.00 & 6.00 \\
\hline Curve & 55.7 & 68.00 & 62.00 & 58.00 & 12.27 & 6.27 & 2.27 & 12.00 & 0.00 & 7.25 \\
\hline Curve & 79.5 & 66.00 & 60.00 & 56.00 & 13.50 & 19.50 & 23.50 & 2.00 & 2.00 & 2.00 \\
\hline Tangent & & 72.00 & 66.00 & 62.00 & & & & 6.00 & 6.00 & 6.00 \\
\hline Curve & 117.4 & 65.00 & 59.00 & 54.00 & 52.36 & 58.36 & 63.36 & 7.00 & 7.00 & 8.00 \\
\hline Tangent & & 72.00 & 65.00 & 59.00 & & & & 7.00 & 6.00 & 5.00 \\
\hline & & & & & 1.00 & 3.00 & 2.00 & 10.00 & 9.00 & 10.00 \\
\hline & & & & & 3.00 & 1.00 & 2.00 & 1.00 & 2.00 & 1.00 \\
\hline & & & & & 2.00 & 2.00 & 2.00 & 0.00 & 0.00 & 0.00 \\
\hline
\end{tabular}

\subsubsection{Global consistency analysis}

Table 8 shows the consistency summary of the test road for the ten established sections. Seven sections present "poor" consistencies and three "acceptable" consistencies and no section as good, within the quality thresholds of design consistency proposed by Polus and Mattar-Habib.

Table 8. Summary of consistencies of the Cusco Urcos and Urcos Cusco roads.

\begin{tabular}{cccccc}
\hline & & \multicolumn{4}{c}{ Cusco - Urcos } \\
Section & Ra & $\Sigma$ & C1 & consistency & Y \\
\hline Section 1 & 5.1 & 3.2 & 0.0293 & Poor & 1.040 \\
Section 2 & 4.7 & 2.1 & 0.1801 & Poor & 0.982 \\
Section 3 & 2.4 & 0.9 & 1.5456 & Fair & 0.587 \\
Section 4 & 3.3 & 1.4 & 0.7905 & Poor & 0.780 \\
Section 5 & 5.5 & 2.3 & 0.0852 & Poor & 1.018 \\
Section 6 & 8.4 & 2.8 & 0.0038 & Poor & 1.050 \\
Section 7 & 6.2 & 2.0 & 0.0971 & Poor & 1.013 \\
Section 8 & 3.6 & 1.8 & 0.4751 & Poor & 0.879 \\
Section 9 & 4.3 & 1.9 & 0.2644 & Poor & 0.951 \\
Section 10 & 3.4 & 1.1 & 1.0175 & Fair & 0.716 \\
\hline
\end{tabular}

Note:

$\mathrm{Ra}=$ Relative area consistency measure $(\mathrm{m} / \mathrm{s})$

$\sigma=$ Standard deviation of operating speeds $(\mathrm{km} / \mathrm{h})$

$\mathrm{C} 1-\mathrm{C} 2=$ Consistency according to Polus-Mattar

$\mathrm{Y}=$ Accident rate according to Polus-Mattar

The results in Table 8 indicate the accident rate by section. For example, in section 1 , there is a probability of accident occurrence of 1.0395 (veh / 106 Veh-km); in other words, one accident per million vehicles in this section, equivalent to one accident every 125 days. 


\subsection{DISTRIBUTION OF THE ACCIDENT RATE ON THE TEST ROAD}

For the 10 sections subject to study, the accidents that have occurred have been distributed according to the field compilation, whose information covers the years 2014 to 2018, associating the consistency with the number of accidents that occurred by progressive and throughout the analysis section.

Table 9. Distribution of the accident rate on the Cusco - Urcos highway. Case: section 2

\begin{tabular}{|c|c|c|c|c|c|c|c|c|c|c|c|c|c|c|c|c|c|}
\hline \multirow{3}{*}{$\begin{array}{c}\mathbf{N} \\
\circ\end{array}$} & \multirow{3}{*}{$\begin{array}{c}\text { Sectio } \\
\text { ns }\end{array}$} & \multirow{3}{*}{$\begin{array}{c}\text { Progressi } \\
\text { ve }\end{array}$} & \multirow{3}{*}{$\begin{array}{c}\text { Elemen } \\
\text { ts }\end{array}$} & \multirow{2}{*}{\multicolumn{4}{|c|}{ Consistency }} & \multicolumn{10}{|c|}{$\begin{aligned} \text { Claims } \\
\end{aligned}$} \\
\hline & & & & & & & & \multicolumn{5}{|c|}{$\begin{array}{c}\text { Distribution of accidents } \\
\text { by progressive }\end{array}$} & \multicolumn{5}{|c|}{$\begin{array}{c}\text { Distribution of accidents } \\
\text { by sections }\end{array}$} \\
\hline & & & & \multicolumn{2}{|c|}{$\begin{array}{l}\text { Cusco- } \\
\text { Urcos }\end{array}$} & \multicolumn{2}{|c|}{$\begin{array}{l}\text { Urcos- } \\
\text { Cusco }\end{array}$} & 201 & 201 & 201 & 201 & 201 & 201 & 201 & 201 & 201 & 201 \\
\hline 5 & \multirow{7}{*}{$\begin{array}{c}\text { Section } \\
2\end{array}$} & $987+447$ & Curve 3 & \multirow{7}{*}{$\begin{array}{c}0.180 \\
1\end{array}$} & \multirow{7}{*}{$\begin{array}{c}\text { Poo } \\
r\end{array}$} & \multirow{7}{*}{$\begin{array}{c}0.000 \\
6\end{array}$} & \multirow{7}{*}{$\begin{array}{c}\text { Poo } \\
\mathrm{r}\end{array}$} & 7 & 1 & 10 & 9 & 8 & \multirow{7}{*}{44} & \multirow{7}{*}{53} & \multirow{7}{*}{34} & \multirow{7}{*}{55} & \multirow{7}{*}{51} \\
\hline 6 & & $987+729$ & $\begin{array}{c}\text { Tangent } \\
3\end{array}$ & & & & & 0 & 1 & 2 & 0 & 0 & & & & & \\
\hline 7 & & $988+278$ & Curve 4 & & & & & 24 & 24 & 4 & 7 & 9 & & & & & \\
\hline 8 & & $988+507$ & $\begin{array}{l}\text { Tangent } \\
4\end{array}$ & & & & & 4 & 7 & 7 & 10 & 5 & & & & & \\
\hline 9 & & $990+810$ & Curve 5 & & & & & 8 & 18 & 10 & 24 & 17 & & & & & \\
\hline $\begin{array}{l}1 \\
0\end{array}$ & & $991+071$ & $\begin{array}{c}\text { Tangent } \\
5\end{array}$ & & & & & 1 & 2 & 1 & 5 & 12 & & & & & \\
\hline $\begin{array}{l}1 \\
1\end{array}$ & & $991+766$ & Curve 6 & & & & & 0 & 0 & 0 & 0 & 0 & & & & & \\
\hline
\end{tabular}

\subsection{HYPOTHESIS TESTING}

\subsubsection{Loss ratio vs. consistency}

Regarding the general hypothesis, where it was postulated that the accident rate is related to the consistency of the road, we have the linear regression statistics, indicated in tables 10 and 11.

Table 10. Loss data, section length, consistency and ADI.

\begin{tabular}{ccccccc}
\hline Section & \multicolumn{2}{c}{ Progresivas } & $\begin{array}{c}\text { Long. } \\
\text { Section } \\
(\mathbf{m})\end{array}$ & $\mathbf{C}$ & $\begin{array}{c}\text { ADI } \\
(\text { Veh/dia) }\end{array}$ & $\begin{array}{c}\text { Claim }^{\left(\mathbf{N}^{\circ}\right.} \\
\text { accid. }\end{array}$ \\
\hline 1 & $984+200$ & $987+083$ & 2882.88 & 0.01 & 8913 & 33 \\
2 & $987+447$ & $991+996$ & 4549.58 & 0.09 & 8913 & 50 \\
3 & $992+730$ & $993+137$ & 406.34 & 1.55 & 8039 & 8 \\
4 & $995+359$ & $997+892$ & 2533.54 & 1.25 & 8039 & 7 \\
5 & $998+640$ & $999+661$ & 1021.64 & 0.43 & 7590 & 8 \\
6 & $999+761$ & $1002+563$ & 2802.01 & 0.05 & 4310 & 9 \\
7 & $1002+660$ & $1006+188$ & 3528.03 & 0.05 & 4310 & 11 \\
8 & $1006+552$ & $1008+955$ & 2402.58 & 0.26 & 4310 & 10 \\
9 & $1009+588$ & $1013+295$ & 3706.64 & 0.21 & 4310 & 20 \\
10 & $1014+043$ & $1015+079$ & 1036.06 & 1.36 & 4310 & 12 \\
\hline
\end{tabular}


Table 11. Regression statistics

Correlation coefficient

$$
0.4493
$$

Coefficient of determination $\mathrm{R}$

$\wedge 2$

0.2019

$\mathrm{R} \wedge 2$ adjusted

Typical error

13.3618

Observations

10.0000

There is a correlation coefficient of 0.4493 , which indicates that $44.93 \%$ of the data of the variables consistency and loss ratio are related, while the coefficient of determination with a value of 0.2019 , indicates that $20.19 \%$ of the variation in Y (loss ratio ), is explained by the regression line.

Table 12. Analysis of variance

\begin{tabular}{cccccc}
\hline & $\begin{array}{c}\text { Degrees of } \\
\text { freedom }\end{array}$ & Sum of squares & Average of squares & F & \multicolumn{2}{c}{ Critical value of } \\
\hline Regression & 1 & 405.2534 & 405.2534 & 2.3419 & 0.1645 \\
Waste & 8 & 1384.3466 & 173.0433 & & \\
Total & 9 & 1789.6000 & & \\
\hline
\end{tabular}

\begin{tabular}{lcccccccc}
\hline & Coefficients & $\begin{array}{c}\text { Standard } \\
\text { error }\end{array}$ & Statistical t & Probability & $\begin{array}{c}\text { Lower } \\
95 \%\end{array}$ & $\begin{array}{c}\text { Higher } \\
95 \%\end{array}$ & $\begin{array}{c}\text { Lower } \\
95.0 \%\end{array}$ & $\begin{array}{c}\text { Higher } \\
95.0 \%\end{array}$ \\
\hline Interception & 22.2686 & 5.7124 & 3.8983 & 0.0046 & 9.0959 & 35.4413 & 9.0959 & 35.4413 \\
Consistency & -10.3778 & 7.2951 & -1.4226 & 0.1927 & -27.2002 & 6.4447 & -27.2002 & 6.4447 \\
\hline
\end{tabular}

From the respective calculations, the following is obtained as a linear regression equation:

$$
y=-10.378 x+22.269
$$

\subsubsection{Loss ratio vs. Average Daily Index}

There is a correlation coefficient of 0.4759 , which means that $47.59 \%$ of the data of the variables Average Daily Index (Vehicle / day) and accident rate are related. The coefficient of determination of 0.2265 indicates that $22.65 \%$ of the variation in $\mathrm{Y}$ is explained by the regression line.

Linear regression equation:

$$
y=0.0031 x-2.98
$$

\subsubsection{Loss ratio vs. element length}

Correlation coefficient of 0.6484 , which indicates that $64.84 \%$ of the data of the variables length of the element and accident rate are related. The coefficient of determination of 0.4204 indicates that $42.04 \%$ of the variation in $\mathrm{Y}$ is explained by the regression line.

Linear regression equation:

$$
y=0.0069 x-0.4307
$$




\subsubsection{Loss ratio vs. consistency, daily average index and section length}

Multiple correlation coefficient of 0.8232 , which indicates that $82.32 \%$ of the data of the variables consistency, daily average index and length of each section, are related to the dependent variable accident rate; Likewise, since it is a multiple regression, it is established that the coefficient of determination adjusted with a value of 0.5165 indicates that $51.65 \%$ of the variation in $\mathrm{Y}$ is explained by the regression line.

The linear regression equation is:

$$
\mathrm{Y}=-19.6462+0.0065 \text { long. section }-2.0354 \text { Consistency }+0.0034 \text { ADI }
$$

An important observation is that when working in a multivariate way, the correlation becomes stronger $(82.32 \%)$; that is, consistency is complemented by the average daily index and the length of the section (although the latter is part of the consistency, because operating speeds are developed at that length). Therefore, the equation will give better results with global variables when it comes to forecasts, where the loss ratio is the inverse of consistency, and the average daily index and length of the section, directly dependent.

Applying the Poisson regression, it is observed that the consistency variable in relation to its significance has a value of 0.178 , being greater than 0.05 , implying that it is not significant, so that its contribution as the only variable in the regression model of Poisson is not very relevant.

In the estimation of the parameter, it is observed that the positive coefficients of the variables Average daily index (veh / day) and length of section $(\mathrm{km})$ with values of 0.000168 and 0.000314 respectively, have a direct relationship with the dependent variable while the consistency variable with a negative value of -0.293 it indicates an inverse relationship with the dependent variable. Its equation is:

$$
y=e^{0.945+0.000168 x_{1}-0.293 x_{2}+0.000314 x_{3}}
$$

\section{CONCLUSIONS}

The degree of consistency of the road studied developed by the continuous model of Polus and Mattar-Habib, shows that the route is inconsistent in eight sections for both directions of circulation. There are geometric elements of the road (curves) whose "supply" (specific speed) is below the "demand" (operating speed).

Regarding the loss ratio-consistency, there is a correlation coefficient of 0.4493 , which indicates that $44.93 \%$ of the data of the variables consistency and loss are related, while the determination coefficient with a value of 0.2019 indicates that $20.19 \%$ of the variation in Y (loss ratio), is explained by the regression line. In the loss ratio versus Average Daily Index, there is a correlation coefficient of 0.4759 
and a determination coefficient of 0.2265 . In the relationship between claims vs. element length, the correlation coefficient is 0.6484 .

Finally, in the multiple loss ratio vs. consistency, daily mean index and section length, when working in a multivariate manner, the correlation becomes stronger $(82.32 \%)$; that is, consistency is complemented by the Average Daily Index and the length of the section. Therefore, the equation will give better results with global variables.

Applying the Poisson regression, it is also observed that the global model is statistically significant; that is, all the independent variables collectively improve the model. Both statistical models are similar in the results.

The specific speeds are those offered by a particular element (radii, superelevations and coefficient of friction typical of each curve), which in this case differ from the operating speeds, which generates inconsistencies, where horizontal curves have been found that are visible compromised by both criteria of Lamm, such as curves $\mathrm{N}^{\circ} 2,6,13,20,34,40$ and 52, which means that they require intervention in their design.

The current ADI of the road (7,213 vehicles / day, on average), has exceeded the transit capacity for which it was designed, and is currently classified as a 1st order highway, which gives it a different status in its layout. It is an incident factor in the accident rate of the road.

In order to minimize the accident rate of the analyzed road, in terms of the geometric design (consistency), a new vertical signaling project must be carried out, mainly on the maximum speed (in accordance with the legal speed), since it has been seen that the existing ones are out of all reality (in the best of cases $\mathrm{Vma}=40 \mathrm{~km} / \mathrm{hr}$ ) and this must correspond to the 98th percentile of vehicle frequencies.

In a specific way, with respect to the mentioned curves, it is appreciated that the superelevations do not respond to the operating speeds, so it is necessary to perform a recalculation of them. 


\section{REFERENCES}

[1] K. Fitzpatrick et al., "Speed prediction for two-lane rural highways," United States. Federal Highway Administration, 2000.

[2] A. García García, F. J. Camacho Torregrosa, and A. M. Pérez Zuriaga, "Consistencia del Diseño Geométrico de Carreteras: Concepto y Criterios," 2013.

[3] J. M. P. Mayora, Procedimientos de estudio, diseño y gestión de medidas de seguridad vial en las infraestructuras. Fundación Agustín de Betancourt, 2004.

[4] G. Koorey, "Incorporating safety into rural highway design," 2009.

[5] J. J. Posada, "Consistencia en el diseño: predicción de la velocidad de operación en carreteras," Ing. Solidar., vol. 10, no. 17, pp. 39-47, 2014.

[6] A. M. Pérez, F. J. Camacho, and A. García, "La velocidad de operación y su aplicación en el análisis de la consistencia de carreteras para la mejora de la seguridad vial," Cuad. Tecnológico la Plataforma Tecnológica Española la Carret., no. 6, p. 64, 2011.

[7] I. B. Anderson, K. M. Bauer, D. W. Harwood, and K. Fitzpatrick, "Relationship to safety of geometric design consistency measures for rural two-lane highways," Transp. Res. Rec., vol. 1658, no. 1, pp. 43-51, 1999.

[8] R. A. Krammes et al., "Horizontal alignment design consistency for rural two-lane highways.," United States. Federal Highway Administration, 1995.

[9] T. Echaveguren, S. Vargas-Tejeda, A. Altamira, and D. Riveros, "Criterios para el análisis de consistencia del diseño geométrico: velocidad, aceleración, visibilidad y confiabilidad,” 2009.

[10] R. Lamm, A. Beck, T. Ruscher, T. Mailänder, S. Cafiso, and G. LACAVA, How to make two-lane rural roads safer-scientific background and guide for practical application. 2006.

[11] A. Polus and C. Mattar-Habib, "New consistency model for rural highways and its relationship to safety," J. Transp. Eng., vol. 130, no. 3, pp. 286-293, 2004.

[12] L. Garach Morcillo, "Medida de la consistencia en carreteras convencionales y su relación con la seguridad vial. Aplicación a la provincia de Granada." Doctoral Dissertation. Universidad de Granada, 2013.

[13] E. Hauer, “The road ahead,” J. Transp. Eng., vol. 131, no. 5, pp. 333-339, 2005.

[14] Ministerio de Transportes y Comunicaciones, Manual de carreteras: Diseño geométrico DG 2018, Primera. Péru, 2018.

[15] J. Stuster, Z. Coffman, and D. Warren, "Synthesis of safety research related to speed and speed management," 1998.

[16] F. G. Praticò and M. Giunta, "Modeling operating speed of two lane rural roads," Procedia-social Behav. Sci., vol. 53, pp. 664-671, 2012. 
[17] J. A. Cirillo, "Interstate system accident research study II, interim report II," Public roads, 1968.

[18] J. Xu, W. Lin, X. Wang, and Y.-M. Shao, "Acceleration and deceleration calibration of operating speed prediction models for two-lane mountain highways," J. Transp. Eng. Part A Syst., vol. 143, no. 7, p. 4017024, 2017.

[19] R. Lamm, B. Psarianos, and T. Mailaender, Highway design and traffic safety engineering handbook. 1999.

[20] P. C. Box and J. C. Oppenlander, "Manual of traffic engineering studies," 1976. 